Article

\title{
Assessing Master Students' Competencies Using Rubrics: Lessons Learned from Future Secondary Education Teachers
}

\author{
Rosa Isusi-Fagoaga ${ }^{1, *(1)}$ and Adela García-Aracil ${ }^{2}$ (D) \\ 1 University Institute of Educational Creativity and Innovation (IUCIE), Universitat de València, \\ 46022 Valencia, Spain \\ 2 INGENIO (CSIC-UPV), Universitat Politècnica de València, 46022 Valencia, Spain; agarcia@ingenio.upv.es \\ * Correspondence: rosa.isusi@uv.es; Tel.: +34-646-545-131
}

Received: 26 October 2020; Accepted: 23 November 2020; Published: 24 November 2020

\begin{abstract}
The aim of this paper is to provide insights into the appropriateness of teaching-learning and evaluation processes using rubrics, for student self-assessments. We studied students enrolled on the Master's in Secondary Education Teaching-Music Specialism course. In the Spanish secondary education system, music is seen as increasing equity and improving student performance in line with the Agenda 2030 Sustainable Development Goals. The training of new teachers and the ongoing professional development of the current teaching force are critical for improving the quality of education. We adopted an action-research approach and obtained feedback from the Masters' students via questionnaires administered at the start and end of the process (pre- and post-test). Our results show that using rubrics as formative and shared assessment tools has a positive influence on students' perceptions of their acquisition of both transversal and specific competencies, as well as demonstrating the utility of rubrics for their future professional practice. However, rubrics on their own are not sufficient to increase the facility for learning and awareness among students.
\end{abstract}

Keywords: sustainable development agenda; higher education; future teachers; music; transversal and specific competencies; rubrics; action-research approach; gender

\section{Introduction}

Competency-based education focuses on outcomes-competencies, which are linked to workforce needs, defined by professional experts and employers [1]. Proponents of competency-based education promote them as a way to improve the correspondence between education and workplace requirements, as competencies are focused on graduates' skills, knowledge, and attitudes rather than solely on the curriculum. However, the competencies acquired via education are required not only to ensure rapid productivity returns on initial entry to the labor market but also to ensure long term employability [2]. Therefore, it is important to understand the effects of various kinds of competencies and the extent to which higher education courses are offering the appropriate competencies to ensure short- and long-term employability [3].

There is broad agreement in terms of the value related to the development of certain competencies to enhance graduates' profiles in the workplace and other settings. These competencies have been described as professional, core, generic, key, specific or non-technical competencies and are crucial for preparing graduates for the labor market and increasing their agency (empowerment) to allow them to be "the authors" of their own lives [4,5]. According to the UN 2030 Agenda for Sustainable Development, becoming an educator requires the individual to master certain key competencies-both generic and context specific-aligned to the notion of transformational learning (i.e., education 
aimed at transforming society) [6,7]. This requires an examination of the literature on specific and generic competencies.

Specific competencies refer to the cognitive prerequisites for adequate performance in a given substantive area [8]. Specific competencies can produce strong productivity gains in the short term. However, technological changes and their effects on day-to-day life, coupled with shifts in the demand for labor, result in specific competencies losing value over time. General competencies refer to the combination of abilities, motivations, and traits required for effective performance in a range of jobs and contexts. General competencies are considered important for long-term employability [9].

Several attempts have been made to integrate specific and general competencies into a more general framework. Bloom [10] distinguishes different levels ranging from entirely context-specific competencies to entirely context-neutral competencies. Action competency models include both general and specific competencies, which they try to incorporate in the cognitive, motivational, and social requirements for successful learning and action [11]. The Bologna Process, which aims to create a coherent European Higher Education Area, has put pressure on higher education institutions to better prepare their students for the world of work/society by promoting transversal competencies, which increase graduates' employability and empowerment [4]. It is precisely in this 'transversality' that the main aim of teaching in higher education is founded, as lecturers work on common axes throughout courses that must have direct transferability to wider society and the world of work. However, there seems to be a disparity between competencies required to be effective in society/work (e.g., decision making, problem solving and management skills) and competencies acquired over the course of university training. Cano [12] presents the results of several international studies, which show that graduates value transversal competencies more highly than specific competencies. However, the ongoing debate on gender differences in academic competencies and on women's underrepresentation in scientific careers tend to focus only on specific or core material and ignore the wider relevance of transversal learning $[3,4,13]$.

In Spain, the development of transversal competencies figure in all teaching programs and university courses regardless of the subject or area of specialization [14]. Some studies suggest that the most common transversal competencies include analysis and synthesis, organization and planning, communication, collaboration, development of interpersonal skills, and use of information and communication technologies [15,16]. In competency-based approaches and in line with the Bologna reforms, the aim is for students to acquire both generic/transversal and specific/disciplinary competencies. In this context, lecturers necessarily focus on their particular subject areas and teach students about formative processes, which allow for application of the competencies gained. However, these approaches need to be accompanied by a robust and multifaceted formative assessment systems [12].

It has been suggested that formative assessment systems are based on three main characteristics-authenticity, cognitive challenge, and judgement-and must include critical reflection and active questioning on the part of the student, which requires commitment from both lecturers and students $[17,18]$. In this view, the development of critical and reflective thinking is central to the student's ability to learn, to reflect on what has been learned, and to interact with peers in a formative and shared/co-assessment process. However, to acquire this reflective component, students need to have some experience of this type of assessment since it implies they must acquire a more active role and sense of responsibility towards their motivation to achieve their tasks and activities [19]. One way to raise students' awareness of assessment criteria is with the use of rubrics.

A rubric is defined as a set of criteria and standards, generally related to learning objectives, which are used to evaluate a level of performance of a task or behavior [20]. Since they are designed according to specific criteria and standards, they allow for impartial assessment. At the same time, rubrics can be used as training tools based on their potential to help students develop a vision of success, providing ongoing feedback on progress and what matters, ranked from excellent to poor [20]. Andrade [21] suggests that deep engagement is required to use rubrics as self- or peer-assessment tools. 
Involving the student in the co-creation of a rubric helps to demonstrate the competencies they need to master and their progress in relation to expectations [22].

Therefore, knowing students' assessment of the rubric-based evaluation process and their views on rubrics are essential, as it helps to better understand the training and evaluation criteria of a subject. This is important for the teaching process in general and the initial training of teachers in particular, since in their future career, they will be required to implement meaningful methodologies and assessment practices in a school environment [23]. The literature points to the relevance of students' perceptions in the analysis of the evaluation process since using rubrics to train future teachers provides the added value of assessing the degree of learning from the perspective of a future evaluator $[19,24,25]$.

In this paper, we present the results of a study of students (future teachers) enrolled in the Master's in Secondary Education Teaching at the University of Valencia. The analysis aimed to determine the appropriateness of using rubrics to evaluate the teaching-learning and competencies acquired, based on students' self-assessment of their competencies. The information obtained was connected with the 2030 sustainable development Quality of Education Goal 4. We involved the students in the construction, development, and use of the rubrics and asked them to reflect on their usefulness. The study aimed to achieve external validity and guide decision-making about the adequacy and appropriateness of the training of future teachers. We focused on the Spanish Innovación Docente e Iniciación a la Investigación Educativa en Música or IDIIEM (Teaching Innovation and Introduction to Educational Research in Music) course offered by the University of Valencia. The IDIIEM model described in this paper could be used by other educational institutions and in other disciplines.

\section{Materials and Methods}

\subsection{Research Context}

In line with the current administrative legal regulations in Spain, the official Master's in Secondary Education Teaching offered by the University of Valencia provides the required qualification, and pedagogical training required of secondary education teachers (in both public and private educational centers). This Master's degree is structured according to different secondary education specialties including: Biology and Geology; Drawing; Economics; Physical Education; Philosophy; Physics and Chemistry; Foreign Languages: German, French, English, Italian and Portuguese; Geography and History; Classical Languages and Cultures: Greek and Latin; Spanish Language and Literature; Mathematics; Music; Counselling; Technology and Industrial Processes; Career Guidance; Vocational Education Specialties: Health, Social, Cultural and Community Services; Business; Trade and Tourism; and Computers Science and Electronic Systems.

We focus on music since it creates educational value for all students regardless of specialization. For instance, it has been shown that among school students from low socio-economic backgrounds, participation in music instruction produces better social and academic outcomes compared with non-participation in music instruction [26,27]. As a result, in the Spanish secondary education system, music is being promoted to increase equity and improve performance, in line with the Agenda 2030 Sustainable Development Goals. Achieving this requires appropriate training for future teachers [28].

At the University of Valencia, the teaching committee of the Master's in Secondary Education Teaching made the decision to include IDIIEM in its 2009 course. The inclusion of music in secondary teaching aimed to enhance students' overall education performance. The IDIIEM teaching guide was in line with the Spanish National Organic Law of Education-LOE/2006, later reformed by the Spanish National Law 8/2013 on the Improvement of Educational Quality and Inclusive Education. According to Ronfeldt and Reininger [29], the IDIIEM teaching guide states that a good teacher should have a combination of different pedagogical knowledge, subject area content knowledge, skills, attitudes and a good understanding of child development in order to provide students with effective communication skills, a strong sense of ethics, and the capacity for renewal and ongoing learning. Since then, IDIIEM includes innovative didactic classroom activities to promote a collaborative environment 
favoring team work, to allow for the cooperative search for information and group discussion of specific research issues, co-assessment, and peer-review of practical activities. To facilitate this, rubrics should be used as an assessment tool to evaluate students' competencies and check the development of attitudes, values, analytical capabilities, comprehension, reasoning, synthesis capabilities and ability to use techniques and strategies which favor lifelong learning.

\subsection{Participants and Procedure}

For our analysis, we chose a cross-sectional study. The fieldwork involved 74 students enrolled in the IDIIEM as part of their secondary education in the academic years 2018/19 and 2019/20. The sample was composed of $46 \%$ women and $54 \%$ men.

The teaching-learning approach was organized during the first quarter of each academic year, between October and February. We employed an action-research method to allow for the collection of both quantitative and qualitative information [30]. The action-research approach involved teachers in a cyclical process of planning, action, observation, reflection, and modification. Each cycle aimed to improve the education process based on learning from the previous cycle. This approach has been used in classroom research and implemented in higher education to improve the quality of teaching and learning [31]. To obtain feedback on the implementation of this method, we administered questionnaires to the students at the beginning and at the end of the process (pre-and post-test; the surveys achieved a $100 \%$ response rate) and held open discussions in the classroom. We were also given access to teachers' field notebooks, which contained comments on students' work.

Fifteen face-to-face classroom sessions were allotted for the development and observation of this teaching-learning approach. Students were organized into groups of four so they could work on team. The explanation of the competencies' meanings, which ones were going to work in the classroom, and the activities to foster them were introduced. At the same time, the criteria for evaluating the learning process, the teaching-learning terminology, and the use of rubrics as a self- and peer-assessment tool were explained. In this action-research teaching-learning approach, the teacher acted as a guide for the student groups, discussing any problems and guiding the development of the work $[12,31]$.

The 23 competencies tested in the classroom and assessed using the rubric were those that the IDIIEM teaching guide highlighted as relevant. Among these 23 competencies, 7 are specific competencies and 16 are transversal competencies (see Table 1).

Some student feedback was gathered via an anonymous online questionnaire administered using Google forms. The design of the questionnaire was validated externally by experts in various competency areas and tested with a small group of postgraduate students. It was split into four sections designed to collect information at different times during the IDIIEM course in the Master's in Secondary Education Teaching program. These sections asked: (i) about the student's self-perception of the level of competencies at the beginning of the first quarter of the academic year; (ii) the student's self-perception of the level of competencies at the end of the first quarter of the academic year; (iii) the student's perception of the peer-evaluation of the competencies identified by each classroom group as relevant in the mid-term of the subject teaching; and (iv) the student's perception of the use of the rubric to assess learning activities at the end of the first quarter of the academic year (see Appendix A for the questionnaire).

In addition to the questionnaire, internal working groups for elaborating the rubric to evaluate competencies were also organized, which involved demonstration and comparison of the different rubrics elaborated by the student groups. The students were later asked to evaluate this collaborative work, explaining how the evaluation process had influenced the teaching-learning process.

The following section presents results based on questionnaire responses related to the teaching-learning approach, the competencies acquired via the IDIIEM course and the utility of the rubric as a formative and assessment tool. 
Table 1. Competencies promoted according to the Teaching Innovation and Introduction to Educational Research in Music's (IDIIEM) teaching guide.

\begin{tabular}{|c|c|}
\hline Transversal Competencies & Specific Competencies \\
\hline $\begin{array}{ll}\text { - } & \text { Be tolerant and respect different points of view } \\
\text { - } & \text { Critical thinking } \\
\text { - } & \text { Bork in a team } \\
\text { - } & \text { Problems solving skills } \\
\text { - } & \text { Adaptability to context } \\
\text { - } & \text { Reflective thinking } \\
\text { - } & \text { Learning to learn } \\
\text { - } & \text { Have initiative and leadership capacity } \\
\text { - } & \text { Independent learning } \\
\text { - } & \text { Be creative } \\
\text { - } & \text { Written communication } \\
\text { - } & \text { Oral communication } \\
\text { - } & \text { Time management } \\
\text { - } & \text { Entrepreneurial capacity } \\
\text { - } & \text { Multidisciplinary thinking }\end{array}$ & $\begin{array}{ll}\text { - } & \text { Applying acquired knowledge } \\
\text { - } & \text { Be able to identify a problem } \\
\text { - } & \text { Be able to innovate and accept } \\
\text { - } & \text { teaching innovation } \\
\text { - } & \text { Fearch and collect information } \\
\text { - } & \text { Planning teaching-learning processes } \\
\text { - } & \text { Design an education action plan }\end{array}$ \\
\hline
\end{tabular}

\section{Results}

The analysis of students' feedback includes analysis of the competencies acquired via the implicit learning approach on the IDIIEM course and information on the utility of the rubric as a formative and evaluation tool.

\subsection{Competencies Acquired in the Classroom: Transversal Versus Specific Competencies}

The online questionnaire asked about 23 items representing transversal (T) and specific (S) competencies promoted by the IDIIEM course. Students were asked to indicate their competency at the beginning of the first quarter of the academic year on a scale ranging from 1 (not at all) to 5 (to a very high extent). Table 2 presents student perceptions of their level of competency.

The students declared high levels of competency in most of the 23 competencies at the beginning of the first quarter of the academic year, with the exception of ability to design an educational action plan (average value less than 3). The results show that the highest values were assigned to transversal competencies, which is expected since the graduates were responding at the beginning of the academic year.

Table 2 also presents the different perceptions of female and male students. We observe that, with the exception of the specific competency associated with being able to innovate and accept teaching innovation, and the transversal competency associated with initiation and leadership capacity, men generally put a lower value on their initial competencies compared with their female peers (although these differences are not statistically significant, as is shown in the last column of Table 2). However, the most statistically significant differences are related to specific competencies in planning teaching-learning processes, knowing how to formulate objectives, ability to design an education action plan, and ability to identify a problem. Among transversal competencies, there are statistically significant differences between women and men in creativity and ability to adapt to context. Our finding that female students perceive their competencies as being higher is in line with Rodríguez Gómez et al. [32] and Martínez Clares and González Morga [33], who evaluated basic competencies (which we describe as transversal competencies) in a group of university students. 
Table 2. Students' self-perception of the level of competencies at the beginning of the first quarter of the academic year (values ranging from 1 to 5 ).

\begin{tabular}{|c|c|c|c|c|}
\hline Competencies & Total & $\begin{array}{l}\text { Women } \\
\text { (W) }\end{array}$ & $\begin{array}{l}\text { Men } \\
\text { (M) }\end{array}$ & $\begin{array}{c}\text { Differencies between } \\
\text { W \& M }\end{array}$ \\
\hline Be tolerant and respect different points of view $(\mathrm{T})$ & 4.49 & 4.59 & 4.40 & 0.19 \\
\hline Critical thinking $(\mathrm{T})$ & 4.22 & 4.29 & 4.15 & 0.14 \\
\hline Work in a team $(\mathrm{T})$ & 4.22 & 4.29 & 4.15 & 0.14 \\
\hline Be able to take responsibility and make decisions $(\mathrm{T})$ & 4.03 & 4.12 & 3.95 & 0.17 \\
\hline Problem solving skills $(\mathrm{T})$ & 4.00 & 4.06 & 3.95 & 0.11 \\
\hline Adaptability to context $(\mathrm{T})$ & 3.97 & 4.23 & 3.75 & $0.48^{* * *}$ \\
\hline Reflective thinking $(\mathrm{T})$ & 3.86 & 4.00 & 3.75 & 0.25 \\
\hline Learning to learn $(\mathrm{T})$ & 3.81 & 3.82 & 3.80 & 0.02 \\
\hline Have initiative and leadership capacity $(\mathrm{T})$ & 3.81 & 3.76 & 3.85 & -0.09 \\
\hline Independent learning $(\mathrm{T})$ & 3.80 & 3.82 & 3.79 & 0.03 \\
\hline Be creative $(\mathrm{T})$ & 3.73 & 4.00 & 3.50 & $0.50 * *$ \\
\hline Written communication $(\mathrm{T})$ & 3.68 & 3.88 & 3.50 & 0.38 \\
\hline Oral communication $(\mathrm{T})$ & 3.68 & 3.70 & 3.65 & 0.05 \\
\hline Time management $(\mathrm{T})$ & 3.65 & 3.82 & 3.50 & 0.32 \\
\hline Entrepreneurial capacity $(\mathrm{T})$ & 3.51 & 3.53 & 3.50 & 0.03 \\
\hline Multidisciplinary thinking (T) & 3.30 & 3.35 & 3.25 & 0.10 \\
\hline Applying acquired knowledge (S) & 3.97 & 4.00 & 3.95 & 0.05 \\
\hline Be able to identify a problem (S) & 3.92 & 4.18 & 3.70 & $0.48^{* *}$ \\
\hline Be able to innovate and accept teaching innovation (S) & 3.84 & 3.76 & 3.90 & -0.14 \\
\hline Search and collect information (S) & 3.81 & 3.94 & 3.70 & 0.24 \\
\hline Formulate objectives (S) & 3.62 & 3.94 & 3.35 & $0.59^{* * *}$ \\
\hline Planning teaching-learning processes $(\mathrm{S})$ & 3.40 & 3.82 & 3.05 & $0.77^{* * *}$ \\
\hline Design an education action plan (S) & 2.97 & 3.29 & 2.70 & $0.59 * *$ \\
\hline
\end{tabular}

${ }^{*}$ Statistically significant differences in averages with ${ }^{* *} p<0.05,{ }^{* * *} p<0.01$. Source: Own elaboration from the IDIIEM questionnaire.

Table 3 presents students' perceptions of their competency levels at the end of the first quarter of the academic year. Students were asked to indicate the extent of a given competency at the end of the IDIIEM course, on a scale ranging from 1 (not at all) to 5 (to a very high extent). It can be seen that levels of transversal competencies (e.g., ability to work in teams, tolerance and respect for different points of view, and independent learning) were perceived as higher than at the beginning of the IDIIEM course. Comparing male and female students, we see that men generally give lower values to the competencies, with the exception of competencies related to critical thinking, working in teams, and independent learning (although these differences are not statistically significant-see the last column of Table 3). Female students' self-evaluations were higher than those of their male peers for specific competencies related to ability to design an education action plan, planning the teaching-learning process, and knowing how to search and collect information, and for the transversal competencies of problem-solving and time management.

Thus, based on the students' assessments of their levels of competencies, we can see that the IDIIEM course contributed positively to competencies development (all values reported were higher at the end of the course). The results are statistically significant for competencies in independent learning (T), multidisciplinary thinking $(\mathrm{T})$, oral communication (T), ability to design an education action plan (S), ability to formulate objectives (S), and time management (S). Section 3.2 discusses the possible contribution of rubrics to these results. 
Table 3. Students' self-perception of the level of competencies at the end of the first quarter of the academic year (values ranging from 1 to 5 ).

\begin{tabular}{|c|c|c|c|c|}
\hline Competencies & Total & $\begin{array}{l}\text { Women } \\
\text { (W) }\end{array}$ & $\begin{array}{l}\text { Men } \\
\text { (M) }\end{array}$ & $\begin{array}{c}\text { Differencies between } \\
\text { W \& M }\end{array}$ \\
\hline Be tolerant and respect different points of view $(\mathrm{T})$ & 4.59 & 4.70 & 4.50 & 0.20 \\
\hline Critical thinking $(\mathrm{T})$ & 4.43 & 4.35 & 4.50 & -0.15 \\
\hline Work in a team $(\mathrm{T})$ & 4.68 & 4.59 & 4.75 & -0.16 \\
\hline Be able to take responsibility and make decisions $(\mathrm{T})$ & 4.43 & 4.47 & 4.40 & 0.07 \\
\hline Problem solving skills $(\mathrm{T})$ & 4.22 & 4.41 & 4.05 & $0.36^{* *}$ \\
\hline Adaptability to context $(\mathrm{T})$ & 4.40 & 4.35 & 4.45 & -0.10 \\
\hline Reflective thinking $(\mathrm{T})$ & 4.34 & 4.41 & 4.25 & 0.16 \\
\hline Learning to learn $(\mathrm{T})$ & 4.27 & 4.29 & 4.25 & 0.04 \\
\hline Have initiative and leadership capacity $(\mathrm{T})$ & 4.16 & 4.17 & 4.15 & 0.02 \\
\hline Independent learning $(\mathrm{T})$ & 4.59 & 4.53 & 4.65 & -0.12 \\
\hline Be creative $(\mathrm{T})$ & 4.11 & 4.06 & 4.15 & -0.09 \\
\hline Written communication $(\mathrm{T})$ & 4.05 & 4.12 & 4.00 & 0.12 \\
\hline Oral communication $(\mathrm{T})$ & 4.35 & 4.35 & 4.35 & 0.00 \\
\hline Time management $(\mathrm{T})$ & 4.16 & 4.35 & 4.00 & 0.35 * \\
\hline Entrepreneurial capacity $(\mathrm{T})$ & 3.83 & 3.88 & 3.80 & 0.08 \\
\hline Multidisciplinary thinking (T) & 4.03 & 4.12 & 3.95 & 0.17 \\
\hline Applying acquired knowledge (S) & 4.23 & 4.31 & 4.16 & 0.15 \\
\hline Be able to identify a problem (S) & 4.30 & 4.41 & 4.20 & 0.21 \\
\hline Be able to innovate and accept teaching innovation (S) & 4.14 & 4.18 & 4.10 & 0.08 \\
\hline Search and collect information (S) & 4.30 & 4.53 & 4.10 & $0.43^{* *}$ \\
\hline Formulate objectives (S) & 4.16 & 4.23 & 4.10 & 0.13 \\
\hline Planning teaching-learning processes $(\mathrm{S})$ & 3.89 & 4.12 & 3.68 & $0.44^{* *}$ \\
\hline Design an education action plan (S) & 3.56 & 3.81 & 3.35 & $0.46^{* *}$ \\
\hline
\end{tabular}

* Statistically significant differences in averages with ${ }^{*} p<0.10,{ }^{* *} p<0.05$, Source: Own elaboration from the IDIIEM questionnaire.

\subsection{Utility of Rubrics in Teaching-Learning Activities}

During the IDIIEM classroom sessions, rubrics were presented to the students as potential assessment tools based on a matrix of learning outcomes along a continuum on the horizontal axis, with the elements (or the criteria) for evaluating learning outcomes shown on the vertical axis. The student-groups began by constructing a rubric with descriptors of competencies and concrete behaviors related to knowledge developed, the application of that knowledge, and space for feedback [12,24]. The virtual classroom provided sources of information on rubrics and their effect on the teaching-learning process to allow the students to participate in the learning process. They gave the students information about how they should proceed and the resources needed to construct a rubric. The groups shared their outcomes with the whole class, including any problems they had encountered. At the end of these presentations, there was a feedback session and the advantages and disadvantages of using rubrics were discussed. Following these activities, the students were asked to respond to an anonymous online questionnaire.

The questionnaire was constructed in line with previous work and included 15 items grouped along 3 dimensions [12,34]: (i) informative and instrumental, aiming to determine the student's familiarity with the rubric, its construction and its use, and its possibilities and limitations (4 items); (ii) formative, aiming to find how much construction and use of the rubric had increased the student's awareness of the different aspects of the teaching-learning process in which they were immersed (5 items); (iii) transfer, aiming to discover the student's perception of the utility of the rubric and whether they planned to use it in their professional work in the future (6 items) (see Appendix A for the questionnaire).

Table 4 presents students' opinions on the usefulness of the rubric in line with the above three dimensions. The students were asked to score on a five point Likert scale (from 1 (not at all) to 5 (to a very high extent)) to what extent the work done in the classroom helped their understanding of the 
functioning of the rubric as students (STUD) (including the instrumental and formative dimensions of the rubric) and as future teachers (FTEACH) (the transfer dimension).

Table 4 shows that for the items related to the informative and instrumental dimensions of the rubric, students stated that they understood what a rubric was and were aware of its usefulness and how to construct it (on average, they gave values higher than 4). In addition, IDIIEM students indicated that they were aware of the limitations of the rubric (i.e., what the rubric does not solve and its other weakness). These results contrast with Puigdellívol and Cano's [34] findings for 141 students involved in initial teacher training for different subjects in the same knowledge area during the second semester of the 2009/10 academic year. The difference might be because our study focused on only one subject and involved a smaller group (74) of students compared with Puigdellóvil and Cano's study [34], in which case our study allowed teachers to deepen and better coordinate instrumental application of the rubric.

Table 4. Students' perception about their experience of the use of rubric in teaching-learning activities (values ranging from 1 to 5 ).

\begin{tabular}{|c|c|c|c|c|}
\hline The Work Done Has Helped to Me in: & Total & $\begin{array}{l}\text { Women } \\
\text { (W) }\end{array}$ & $\begin{array}{c}\text { Men } \\
\text { (M) }\end{array}$ & $\begin{array}{l}\text { Differencies between } \\
\text { W \& M }\end{array}$ \\
\hline \multicolumn{5}{|l|}{ Informative and Instrumental Dimension } \\
\hline Understanding what a rubric is (STUD) & 4.67 & 4.76 & 4.58 & 0.18 \\
\hline Perceiving clearly the utility of the rubric (STUD) & 4.30 & 4.70 & 4.16 & 0.54 * \\
\hline Knowing how to elaborate a rubric (STUD) & 4.28 & 4.29 & 4.26 & 0.03 \\
\hline $\begin{array}{c}\text { Being aware of rubric limits: what it does not resolve } \\
\text { and its weaknesses (STUD) }\end{array}$ & 4.56 & 4.65 & 4.47 & 0.18 \\
\hline \multicolumn{5}{|l|}{ Formative Dimension } \\
\hline $\begin{array}{l}\text { Better understanding of the objectives of the activity } \\
\text { (STUD) }\end{array}$ & 4.26 & 4.12 & 4.37 & $-0.25^{*}$ \\
\hline $\begin{array}{l}\text { Better knowledge of the evaluation criteria of the } \\
\text { activity (STUD) }\end{array}$ & 4.50 & 4.59 & 4.42 & 0.17 \\
\hline Greater awareness of learnings that worked (STUD) & 4.14 & 4.29 & 4.00 & $0.29 *$ \\
\hline $\begin{array}{l}\text { Getting more involved with the contents and activities } \\
\text { (STUD) }\end{array}$ & 3.97 & 4.23 & 3.74 & $0.49 *$ \\
\hline Achieving better results/performance (STUD) & 3.97 & 4.06 & 3.89 & 0.17 \\
\hline \multicolumn{5}{|l|}{ Transfer Dimension } \\
\hline Using it in my professional practice (FTEACH) & 4.06 & 4.18 & 3.95 & 0.23 \\
\hline $\begin{array}{l}\text { Clarifying what I will ask for my future students } \\
\qquad \text { (FTEACH) }\end{array}$ & 4.44 & 4.53 & 4.37 & 0.16 \\
\hline $\begin{array}{c}\text { Enabling my future students to see what is expected of } \\
\text { them with greater clarity (FTEACH) }\end{array}$ & 4.36 & 4.53 & 4.21 & $0.32 *$ \\
\hline $\begin{array}{l}\text { Involving my future students in their own evaluation } \\
\qquad(\text { FTEACH) }\end{array}$ & 4.22 & 4.29 & 4.16 & 0.13 \\
\hline Motivating my future students to learn (FTEACH) & 3.61 & 3.65 & 3.58 & 0.07 \\
\hline
\end{tabular}

With respect to formative dimension items, the students perceived the rubric as providing familiarity with evaluation criteria and objectives of classroom activities (on average, they gave values higher than 4). However, they felt less aware of the learning process. This could be interpreted as a weakness associated with use of the rubric and might be due to the small amount of time available to use the rubric in the classroom. This finding is similar to that of Puigdellívol and Cano [34], who show that the rubric on its own does not guarantee acquisition of a high level of learning awareness.

The survey items related to the rubric's transfer dimension indicate that students appreciated the usefulness of the rubric as a pedagogic tool, both as students and as future teachers. However, its use for promoting learning scored lower than the other items (average score 3.61). This is in line with the findings of Panadero et al. [24], who were unable to draw any firm conclusions about improvements to students' learning because the results depended on the students' motivation i.e., more motivated 
students took more advantage of the learning help offered by the rubric if this was congruent with their learning goals. Thus, it is possible for results to point in different directions regarding the effectiveness of the rubric as a learning tool.

Regarding the differences between female and male students, Table 4 shows slight statistically significant differences in mean values with respect to the utility of the rubric as a training and evaluation tool, although female students generally perceived it as more useful than their male peers.

\section{Discussion}

The objective of this study was to analyze the appropriateness of using rubrics to evaluate the teaching-learning approach and to identify the relevance of the students' self-assessment of their competencies. We conducted a study of students enrolled in the Master's in Secondary Education Teaching-Music Specialism at the University of Valencia. In Spain, music education, especially at secondary level, is being promoted as a tool for increasing equity and improving students' performance. Arts training is associated with better social outcomes and higher academic achievement since music allows for a stronger connection to the focal school, based on its cultural relevance [26-28,35]. Music instruction can and will increase educational opportunities for students of secondary education, and providing better preparation for teachers in music instruction will help achieve this end, which is closely related to the core Agenda 2030 Sustainable Development Goals.

We proposed rubrics as methodological, formative, and evaluation tools to introduce innovative teaching practices and improve teaching-learning quality on the IDIIEM course in the Master's in Secondary Education Teaching curriculum. Assessing competencies using rubrics implies the need to establish evaluation criteria, the different levels of transversal and specific competencies, and how they contribute to the students' development.

We observed that evaluating competencies using rubrics increased student awareness of what they could learn from the various activities. We compared their perception of their level of competencies at the beginning and end of the IDIIEM module and found that it had increased at the end of the course. The significant perceived improvements of competencies at the end of the course is indicative of the value and importance of this type of assessment for the education process. However, although the findings from our study and that conducted by Panadero et al. [24] were positive for the use of rubrics, more research is needed on how much of this improvement (what percentage) is due to use of the rubric and how much is due to other teaching-learning components such as group work, written assignments, oral presentations, class attendance, virtual readings, etc., or experience outside the classroom (e.g., work experience during the academic year).

On average, students ranked transversal competencies higher than specific competencies, which supports the findings in $[12,13]$. However, perceptions of transversal learning differed between male and female students. Overall, female students self-evaluated the specific competencies gained through the IDIIEM course higher than their male peers. This might be the result of cultural beliefs about gender in relation to a teaching career. In other words, cultural beliefs and gender stereotypes might bias individual perceptions of competencies [36]. In general, if certain specific competencies are considered necessary for a particular career, gender differences in the perception of tasks can result in gender differences in commitment to the particular career. For instance, there is substantial evidence showing that mathematics is associated with males, and even among individuals who do not believe that men are better at math than women, there is a belief that others will adhere to this stereotype, which will influence career-decisions, behaviors, and judgments [4,37]. While efforts have been made to reduce gender stereotyping with regards to different jobs, this bias in paid work persists. A focus on how specific competencies are perceived is crucial to understanding the stratification on both the supply- and demand-sides of the labor market and the cultural schemas for interpreting or making sense of the social world.

Our implementation of rubrics as an innovative tool for training and assessment shows that, on average, the students understood what rubrics are, their usefulness, and how they are constructed. 
Classroom activities helped students to understand the limitations related to using rubrics. This finding is important due to students acquiring the knowledge and skills necessary to apply rubrics, and they stated their intention in implementing them in future professional practice. In particular, the results for the informative and instrumental dimensions of the rubric, which contrast with Puigdellívol and Cano's [34] findings, show on the one hand, the importance of teaching relatively small numbers of students when it enhances the implementation of a student-centered teaching-learning model based on competencies development (less than 25 per class), and on the other hand, that applying rubrics to different subjects, as in Puigdellívol and Cano [34], requires coordination among teachers to increase the effectiveness of the rubric as a training and self-assessment tool. Active teaching-learning based on the development of competencies is more time consuming and involves greater workload than the mere teaching of knowledge [25]. It would be interesting to investigate the coordination of teaching activities and the role of the institutional organization supporting that cooperation in more detail. A focus on organizational actions would inform strategic decisions about which components should be targeted to enhance coordination and education quality, such as the encouragement of teachers' practices in active teaching-learning methodologies and associated assessment practices.

The formative dimension of the rubric showed that there was a difference between the perceived ease of use of the rubric and the limitations on learning that it imposed. However, this finding should be interpreted with caution, especially the positive evaluation of the transfer dimension, which is in line with Panadero et al.'s [24] findings. This paradox leads to further explorations in analyzing the use and utility of rubrics in other additional subjects in the Master's degree-Music Specialism and in different Master's Specialties in secondary education, expanding the framework of our analysis.

Our study has demonstrated how use of a formative and shared assessment system in higher education has a positive influence on perception of the acquisition of competencies. This is a relevant result since we show that the use of rubrics improves students' perceptions of their acquisition of both transversal and specific competencies. In this context, the preparation of new teachers and the ongoing professional development of current teachers are key to improve education.

This study has some limitations. It seems that providing students with rubrics is not enough to achieve mastery of awareness learning skills, and this requires complementary methods including more teacher intervention (more time spent using the rubric), incentives for student learning, and institutional support to coordinate different teaching tasks related to other subjects in the same and other knowledge areas, to enable a multidisciplinary teaching-learning approach.

Author Contributions: R.I.-F. and A.G.-A. contributed equally to this work. All authors have read and agreed to the published version of the manuscript.

Funding: This research was funded by the National R\&D Program of the Spanish Ministry of Science, Innovation and Universities, grant number RTI2018-101722-B-I00 'Spanish Universities Involvement in Social Innovation Activities' (SUISIA) The views expressed in this paper are not necessarily the views of that organization.

Acknowledgments: The authors want to thank to the students enrolled in the IDIIEM course for their collaboration in responding to the on-line questionnaire, the academic experts involved in the Master in Secondary Education Teaching at the University of Valencia, and the INGENIO research institute for administrative support.

Conflicts of Interest: The authors declare no conflict of interest.

\section{Appendix A}

Questionnaire-Master's in Secondary Education Teaching-subject IDIIEM

Section 1. Pretest-students' level of competencies at the beginning of the academic year

1. Gender: $\square$ Female $\square$ Male

2. What was your highest qualification before you entered this Master's?

Official intermediate music education degree

Degree in Primary Education Teaching 
Degree in Kindergarten Education Teaching

$\square$ Other university degree

3. Students' own level of competencies. Likert scale from 1 (not at all) to 5 (at very high extent)

\begin{tabular}{|c|c|c|c|c|c|}
\hline Competencies & 1 & 2 & 3 & 4 & 5 \\
\hline \multicolumn{6}{|l|}{ Be tolerant and respect different points of view $(\mathrm{T})$} \\
\hline \multicolumn{6}{|l|}{ Critical thinking $(\mathrm{T})$} \\
\hline \multicolumn{6}{|l|}{ Work in a team $(\mathrm{T})$} \\
\hline \multicolumn{6}{|c|}{ Be able to take responsibility and make decisions $(\mathrm{T})$} \\
\hline \multicolumn{6}{|l|}{ Problem solving skills (T) } \\
\hline \multicolumn{6}{|l|}{ Adaptability to context $(\mathrm{T})$} \\
\hline \multicolumn{6}{|l|}{ Reflective thinking $(\mathrm{T})$} \\
\hline \multicolumn{6}{|l|}{ Learning to learn $(\mathrm{T})$} \\
\hline \multicolumn{6}{|l|}{ Have initiative and leadership capacity $(\mathrm{T})$} \\
\hline \multicolumn{6}{|l|}{ Independent learning $(\mathrm{T})$} \\
\hline \multicolumn{6}{|l|}{ Be creative $(\mathrm{T})$} \\
\hline \multicolumn{6}{|l|}{ Writing communication $(\mathrm{T})$} \\
\hline \multicolumn{6}{|l|}{ Oral communication $(\mathrm{T})$} \\
\hline \multicolumn{6}{|l|}{ Time management $(\mathrm{T})$} \\
\hline \multicolumn{6}{|l|}{ Entrepreneurial capacity $(\mathrm{T})$} \\
\hline \multicolumn{6}{|l|}{ Multidisciplinary thinking $(\mathrm{T})$} \\
\hline \multicolumn{6}{|l|}{ Applying acquired knowledge (S) } \\
\hline \multicolumn{6}{|l|}{ Be able to identify a problem (S) } \\
\hline \multicolumn{6}{|c|}{ Be able to innovate and accept teaching innovation $(S)$} \\
\hline \multicolumn{6}{|l|}{ Search and collect information (S) } \\
\hline \multicolumn{6}{|l|}{ Formulate objectives (S) } \\
\hline \multicolumn{6}{|l|}{ Planning teaching-learning processes (S) } \\
\hline Design an education action plan (S) & & & & & \\
\hline
\end{tabular}

4. Please write down the top five competencies from your point of view:

a.

b.

c.

d.

e.

5. Please let us know if you started your musical studies outside of formal education

Yes, I started during kindergarten school-age (3-5 years old)

Yes, I started during primary education school-age (6-12 years old)

Yes, I started during secondary education school-age (13-16 years old)

Yes, I started during post-secondary education school-age (17-18 years old)

No, I did not.

6. What is your parent's highest educational level?

\begin{tabular}{ccc}
\hline Level of Education & Mother & Father \\
\hline Primary Education & & \\
Secondary Education & & \\
Higher Education & \\
Not applicable & \\
\hline
\end{tabular}


Section 2. Post-test-students' level of competencies at the end of the academic year

7. Level of competencies acquired. Likert scale from 1 (not at all) to 5 (at very high extent)

\begin{tabular}{|c|c|c|c|c|c|}
\hline Competencies & 1 & 2 & 3 & 4 & 5 \\
\hline \multicolumn{6}{|l|}{ Be tolerant and respect different points of view $(\mathrm{T})$} \\
\hline \multicolumn{6}{|l|}{ Critical thinking $(\mathrm{T})$} \\
\hline \multicolumn{6}{|l|}{ Work in a team (T) } \\
\hline \multicolumn{6}{|l|}{ Be able to take responsibility and make decisions $(\mathrm{T})$} \\
\hline \multicolumn{6}{|l|}{ Problems solving skills $(\mathrm{T})$} \\
\hline \multicolumn{6}{|l|}{ Adaptability to context (T) } \\
\hline \multicolumn{6}{|l|}{ Reflective thinking (T) } \\
\hline \multicolumn{6}{|l|}{ Learning to learn $(\mathrm{T})$} \\
\hline \multicolumn{6}{|l|}{ Have initiative and leadership capacity ( $\mathrm{T}$ ) } \\
\hline \multicolumn{6}{|l|}{ Independent learning $(\mathrm{T})$} \\
\hline \multicolumn{6}{|l|}{ Be creative $(\mathrm{T})$} \\
\hline \multicolumn{6}{|l|}{ Writing communication (T) } \\
\hline \multicolumn{6}{|l|}{ Oral communication $(\mathrm{T})$} \\
\hline \multicolumn{6}{|l|}{ Time management $(\mathrm{T})$} \\
\hline \multicolumn{6}{|l|}{ Entrepreneurial capacity (T) } \\
\hline \multicolumn{6}{|l|}{ Multidisciplinary thinking (T) } \\
\hline \multicolumn{6}{|l|}{ Applying acquired knowledge (S) } \\
\hline \multicolumn{6}{|l|}{ Be able to identify a problem (S) } \\
\hline \multicolumn{6}{|c|}{ Be able to innovate and accept teaching innovation (S) } \\
\hline \multicolumn{6}{|c|}{ Search and collect information (S) } \\
\hline \multicolumn{6}{|l|}{ Formulate objectives (S) } \\
\hline \multicolumn{6}{|l|}{ Planning teaching-learning processes (S) } \\
\hline Design an education action plan (S) & & & & & \\
\hline
\end{tabular}

8. Please, write down the top five competencies from your point of view:
a.
b.
c.
d.
e.

9. To what extent have the following modes of teaching and learning influenced in the development of your competencies? Likert scale from 1 (not at all) to 5 (at very high extent)

\begin{tabular}{ccccccc}
\hline Modes of Teaching and Learning & 1 & 2 & 3 & 4 & 5 \\
\hline Lectures & & & & & \\
Participation and discussions at the classroom & & & & & \\
Group assignments & & & & & \\
Written assignments & & & & & & \\
Oral presentation by students & & & & & \\
Teacher as the main source of information & & & & & \\
Theories, paradigms and other material shared on-line & & & & & \\
\hline
\end{tabular}

Section 3. Post-test. Student group's evaluation of relevant competencies that were gained in the classroom.

10. Students' perceptions about relevant competencies for the IDIIEM subject. Likert scale from 1 (not at all) to 5 (at very high extent) 


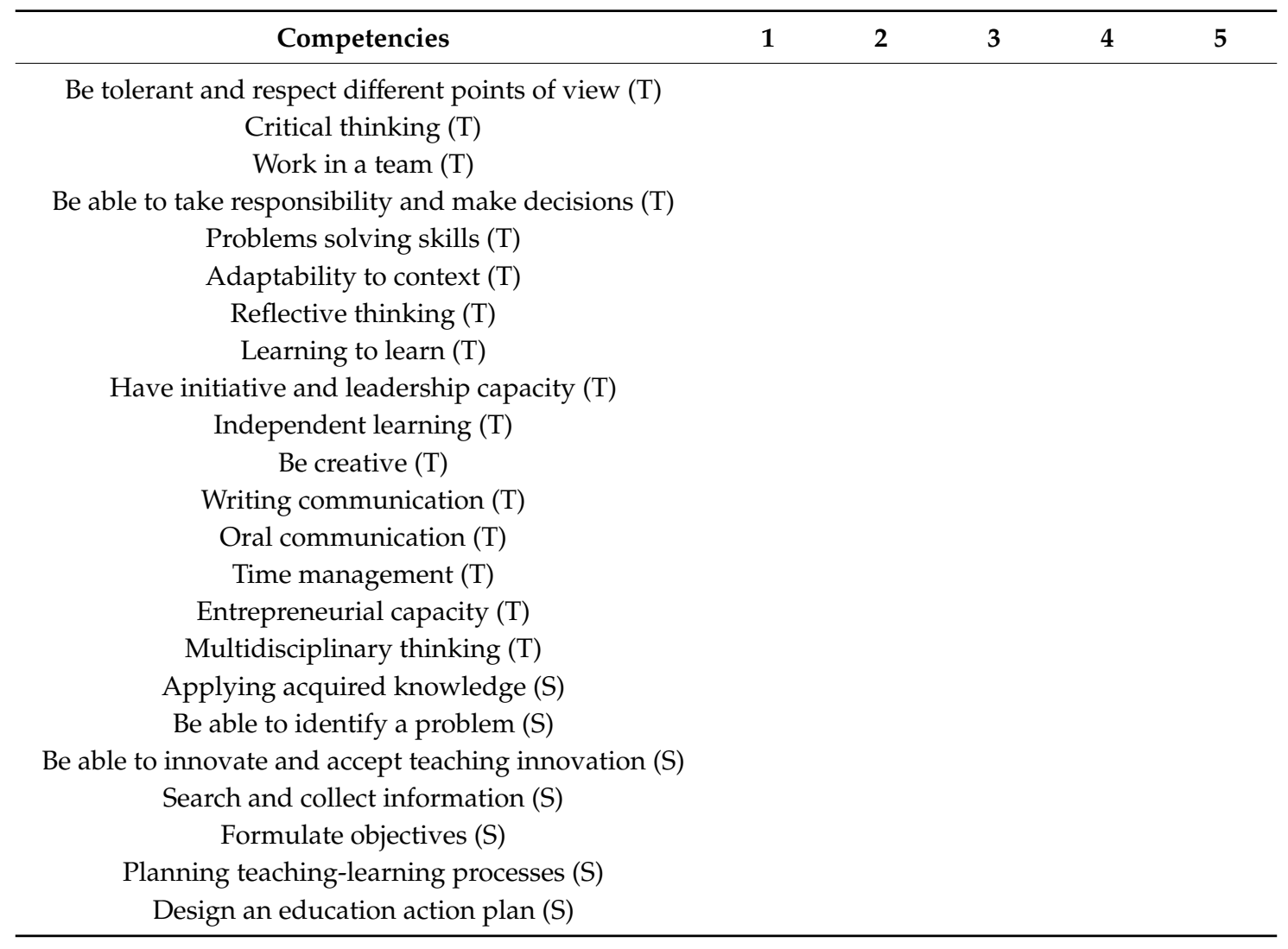

Section 4. Post-test. Students' perception about the use and utility of the rubric.

11. Please indicate the use and utility of the rubric that was used in your classroom. Likert scale from 1 (not at all) to 5 (at very high extent)

\begin{tabular}{|c|c|c|c|c|c|}
\hline The Work Done Has Helped to Me in: & 1 & 2 & 3 & 4 & 5 \\
\hline \multicolumn{6}{|l|}{ Informative and Instrumental Dimension } \\
\hline \multicolumn{6}{|l|}{ Understanding what a rubric is (STUD) } \\
\hline \multicolumn{6}{|l|}{ Perceiving clearly the utility of the rubric (STUD) } \\
\hline \multicolumn{6}{|l|}{ Knowing how to elaborate a rubric (STUD) } \\
\hline \multicolumn{6}{|l|}{$\begin{array}{l}\text { Being aware of rubric limits: what it does not resolve and its } \\
\text { weaknesses (STUD) }\end{array}$} \\
\hline Formative Dimension & & & & & \\
\hline
\end{tabular}

Having a greater understanding the objectives of the activity (STUD)

Having a greater knowledge of the evaluation criteria of the activity

Being more aware of the learnings at work (STUD)

Getting more involved with contents and activities (STUD)

Achieving better results/performance (STUD)

Transfer Dimension

Using it in my professional practice (FTEACH)

Clarifying what I will ask for my future students (FTEACH)

Enabling my future students to better understand what is expected of them (FTEACH)

Involving my future students in their own evaluation (FTEACH)

Motivating my future students to learn (FTEACH) 
Comments and suggestions:

Thank you very much for your cooperation!

\section{References}

1. Allen, J.; Ramaekers, G.; van der Velden, R. Measuring competencies of higher education graduates. In Enhancing Alumni Research: European and American Perspectives, New Directions for Institutional Research; Weerts, D.J., Vidal, J., Eds.; Jossey-Bass: San Francisco, CA, USA, 2005; pp. 49-59.

2. Teijeiro, M.; Rungo, P.; Freire, M.J. Graduate competencies and employability: The impact of matching firms' needs and personal attainments. Econ. Educ. Rev. 2013, 34, 286-295. [CrossRef]

3. García-Aracil, A.; Monteiro, S.; Almeida, L.S. Students' perceptions of their preparedness for transition to work after graduation. Act. Learn. High. Educ. 2018, 1-14. [CrossRef]

4. García-Aracil, A.; Isusi-Fagoaga, R. Appropriateness of education and employment. Soc. Educ. 2019, 51, 55-61. [CrossRef]

5. Nussbaum, M. Education for citizenship in an era global connection. Stud. Philos. Educ. 2002, 21, 289-303. [CrossRef]

6. United Nations. About the Sustainable Development Goals. 2015. Available online: https://www.un.org/ sustainabledevelopment/sustainable-development-goals/ (accessed on 30 September 2020).

7. Giangrande, N.; White, R.M.; East, M.; Jackson, R.; Clarke, T.; Coste, M.S.; Penha-Lopes, G. A Competency Framework to Assess and Activate Education for Sustainable Development: Addressing the UN Sustainable Development Goals 4.7 Challenge. Sustainability 2019, 11, 2832. [CrossRef]

8. Weinert, F.E. Concept of competence: A conceptual clarification. In Defining and Selecting Key Competencies; Rychen, D.S., Salganik, L.H., Eds.; Hofgrefe \& Huber: Washington, DC, USA, 2001.

9. Monteiro, S.; Almeida, L.S.; Gomes, C.; Sinval, J. Employability profiles of higher education graduates: A person-oriented approach. Stud. High. Educ. 2020. [CrossRef]

10. Bloom, B.S. (Ed.) Taxonomy of Educational Objectives. Handbook I: Cognitive Domain; McKay: New York, NY, USA, 1956.

11. Laguna-Sánchez, P.; Abad, P.; de la Fuente-Cabrero, C.; Calero, R. A University training programme for acquiring entrepreneurial and transversal employability skills, a students' assessment. Sustainability 2020, 12, 796. [CrossRef]

12. Cano, E. Las rúbricas como instrumento de evaluación de competencias en Educación Superior: ¿Uso o abuso? Revista de Curric. y Form. del Profr. 2015, 19, 265-280.

13. Velasco, P.J.; Learreta, B.; Kober, C.; Tan, I. Faculty perspective on competency development in higher education: An International study. High. Learn. Res. Commun. 2014, 4, 85-100. [CrossRef]

14. MEC—Ministerio de Educación y Ciencia. Directrices Para la Elaboración de TÍTULOS universitarios de Grado y Máster; MEC: Madrid, Spain, 2006.

15. Muñoz, D.A.; Queupil, J.P.; Fraser, P. Assessing Collaboration Networkd in Educational Research: A Co-Authorships-Based Social Network Analysis Approach. Int. J. Educ. Manag. 2016, 30, 416-436. [CrossRef]

16. Larsen, V. Transversal knowledge formations in professional bachelor education employing problem based learning (PBL). J. Probl. Based Learn. High. Educ. 2013, 1, 53-71.

17. López-Pastor, V.; Sicilia-Camacho, A. Formative and shared assessment in higher education. Lessons learned and challenges for the future. Assess. Eval. High. Educ. 2017, 42, 77-97. [CrossRef]

18. Villarroel, V.; Bloxham, S.; Bruna, D.; Bruna, C.; Herrera-Seda, C. Authentic assessment: Creating a blueprint for course design. Assess. Eval. High. Educ. 2018, 43, 840-854. [CrossRef]

19. Hortigüela Alcalá, D.; Palacios Picos, A.; López Pasto, V. The impact of formative and shared or co-assessment on the acquisition of transversal competences in higher education. Assess. Eval. High. Educ. 2019, 44, 933-945. [CrossRef] 
20. Reddy, Y.M.; Andrade, H. A review of rubric use in higher education. Assess. Eval. High. Educ. 2010, 35, 435-448. [CrossRef]

21. Andrade, H.L. A critical review of research on student self-assessment. Front. Educ. 2019, 4, 87. [CrossRef]

22. Egodawatle, G. A rubric to self-assess and peer-assess mathematical problem solving tasks of college students. Acta Didact. Napoc. 2010, 3, 75-88.

23. Martínez Abad, F.; Bielva Calvo, M.; Herrera García, M.E. Evaluación, formación e innovación en competencias informales para profesores y estudiantes de Educación Secundaria. Revista Educación 2017, 376, 110-134.

24. Panadero, E.; Alonso-Tapia, J.; Reche, E. Rubrics vs self-assessment scripts effect on self-regulation, performance and self-efficacy in pre-service teachers. Stud. Educ. Eval. 2013, 39, 125-132. [CrossRef]

25. Pui, P.; Yuen, B.; Goh, H. Using a criterion-referenced rubric to enhance student learning: A case study in a critical thinking and writing module. High. Educ. Res. Dev. 2020. [CrossRef]

26. Doyle, J.L. Cultural Relevance in Urban Music Education: A Synthesis of the Literature. Natl. Assoc. Music Educ. 2014, 32, 44-51. [CrossRef]

27. García-Aracil, A.; Neira, I.; Albert, C. Social and Cultural Capital Predictors of Adolescents' Financial Literacy: Family and School Influences. Revista Educación 2016, 374, 94-117.

28. MEC. Directrices para la elaboración de Títulos Universitarios de Grado y Máster. Propuesta de 21 de diciembre de la Secretaría de estado de Universidades e Investigacion-Guidelines for the Preparation of University Degrees at Undergraduate and Masters Level. Proposal 21 December of the State Secretary of Universities and Research 2006a; MEC: Madrid, Spain, 2006.

29. Ronfeldt, M.; Reininger, M. More or better student teaching? Teach. Teach. Educ. 2012, 28, 1091-1106. [CrossRef]

30. Lewin, K. Action research and minority problems. J. Soc. Issues 1946, 2, 34-46. [CrossRef]

31. Jones, J.; Masika, R. Appreciative inquiry as a developmental research approach for higher education pedagogy: Space for the shadow. High. Educ. Res. Dev. 2020. [CrossRef]

32. Rodríguez Gómez, G.; Ibarra Saiz, M.S.; Cubero Ibáñez, J. Competencias básicas relacionadas con la evaluación. Un estudio sobre la percepción de los estudiantes universitarios. Educ. XXI 2018, 21, 181-208. [CrossRef]

33. Martínez Clares, P.; González Morga, N. The domain of transversal competences in Higher Education in different training contexts. Educação e Pesquisa 2019, 45. [CrossRef]

34. Puigdellívol, I.; Cano, E. Las rúbricas en los estudios de Educación. In La evaluación de competencies en la educación superior. Las Rúbricas Como Instrumento de Evaluación; Buján, K., Rekalde, I., Aramendi, P., Eds.; MAD: Sevilla, Spain, 2011; pp. 131-156.

35. Isusi-Fagoaga, R. Innovación, interdisciplinariedad y educación artística en la formación docente universitaria. Dedica. Revista Educaçao Humanid. 2018, 13, 43-53.

36. García-Aracil, A. Effects of College Programme Characteristics on Graduates' Performance. High. Educ. 2015, 69, 735-757. [CrossRef]

37. Correll, S.J. Constraints into Preferences: Gender, Status, and Emerging Career Aspirations. Am. Sociol. Rev. 2004, 69, 93-113. [CrossRef]

Publisher's Note: MDPI stays neutral with regard to jurisdictional claims in published maps and institutional affiliations.

(C) 2020 by the authors. Licensee MDPI, Basel, Switzerland. This article is an open access article distributed under the terms and conditions of the Creative Commons Attribution (CC BY) license (http://creativecommons.org/licenses/by/4.0/). 